Аналіз лікарських препаратів

Analysis of drugs

Рекомендована д. біол. наук, профр. Л. С. Фірою

УДК 615.31'792'532-304.2.07

\title{
ЩОДО СТАНДАРТИЗАЦІї СУБСТАНЦІї ГІПЕРТРИЛУ
}

\author{
СЛ. І. Кучеренко
}

\author{
Запорізький державний медичний університет \\ НВО «Фарматрон»
}

Резюме: від наявності високоефективних конкурентоспроможних лікарських засобів вітчизняного виробництва залежить ефективність надання лікарської допомоги населенню України. Особливо це стосується лікарських засобів для лікування захворювань серцево-судинної системи. Вищезазначене спонукало до створення принципово нового антиангінального та антигіпертензивного препарату оригінальної структури - гіпертрилу. Тому метою нашої роботи стала розробка методів стандартизації отриманої субстанції. На сьогодні велику увагу приділяють новим сучасним методам стандартизації субстанцій. В ході проведених досліджень розроблено методики стандартизації, а саме - ідентифікації та кількісного визначення вмісту субстанції гіпертрилу, які є чутливими, об'єктивними, надійними та відтворюваними. В подальшому розроблені методики якісного та кількісного визначення планується ввести в МКЯ на субстанцію гіпертрилу.

Ключові слова: субстанція, гіпертрил, стандартизація, ідентифрікація, неводне титрування.

Вступ. Зростання смертності та інвалідності від серцево-судинних захворювань - проблема не лише закладів охорони здоров'я, це - соціальна проблема всього суспільства. Відповідно, і шляхи вирішення цієї проблеми повинні бути загальнодержавними. Від наявності високоефективних конкурентоспроможних лікарських засобів вітчизняного виробництва залежить есрективність надання лікарської допомоги населенню України. Особливо це стосується лікарських засобів для лікування захворювань серцевосудинної системи, а саме, ішемічної хвороби серця, артеріальної гіпертензії, інсраркту міокарда та гострої серцевої недостатності. Тому розробка засобів лікування цих патологій серцево-судинної системи є актуальною задачею сучасної медицини і фармації $[8,10$, $11,12]$. Згідно з рекомендаціями Європейського співтовариства кардіологів, важливими компонентами комплексної терапії серцевої недостатності, особливо після перенесеного інсраркту міокарда, $є$ наступні групи препаратів: Љ-адреноблокатори, інгібітори АПФ (ангіотензинперетворювальний фермент) та діуретики. Найбільш ефективним вважається застосування ß-адреноблокаторів останнього покоління [8, 10]. У зв'язку 3 вищесказаним, першочерговою задачею фрармацевтичної і медичної науки є створення та удосконалення нових високоефективних і безпечних лікарських засобів, застосування яких сприяло б зменшеню ускладнень, а також покращенню якості та подовженню життя людини. Вищезазначене спонукало до створення принципово нового антиангінального та антигіпертензивного препарату оригінальної структури, який матиме мінімум побічних ефектів $[1,6,7]$. Співробітники кафредри фрармацевтичної хімії ЗДМУ спільно 3 фрахівцями НВО «Фарматрон» отримали нову оригінальну сполуку - похідне 4-аміно-1,2,4триазолу (препарат Гіпертрил). Гіпертрил - бромід 1-(ß-френілетил)-4-аміно-1,2,4-триазолія - лікарський засіб, який проявляє антигіпертензивні, протиішемічні та антиоксидантні властивості $[6,7] .3$ огляду на вищесказане, вважаємо необхідним та своєчасним розробити методики контролю якості (МКЯ) на отриману субстанцію. Тому метою нашої роботи стала розробка методів стандартизації субстанції гіпертрилу.

Методи дослідження. На сьогодні велику увагу приділяють новим сучасним методам стандартизації субстанцій $[2,3,9]$. 3 огляду на хімічну будову гіпертрилу (рис. 1) та методи її отримання було розроблено проект методики контролю якості (МКЯ) на субстанцію [5].

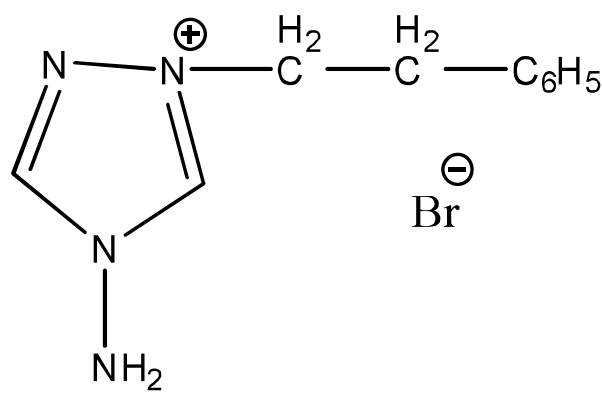

Рис. 1. Структурна фрормула гіпертрилу.

При розробці МКя ми спиралися на новітні та сучасні методи стандартизації, запропоновані Державною Фармакопеєю України (ДФУ) та міжнародною Європейською Фармакопеєю $[3,9]$. Згідно з їх вимогами до специфрікації на субстанцію гіпертрилу вне-

ISSN 2312-0967. Фармацевтичний часопис. 2015. № 2 
сено такі показники: опис, розчинність, температура плавлення, прозорість розчину, кольоровість, $\mathrm{pH}$, супровідні домішки, залишкова кількість органічних розчинників (2-пропанол), важкі метали, сульфратна зола, мікробіологічна чистота та кількісне визначення. В даній роботі ми розглянемо деякі 3 них, а саме ідентиорікацію та кількісне визначення гіпертрилу.

Результати й обговорення. 3 огляду на хімічну будову гіпертрилу (рис. 1), для ідентифрікації субстанції запропоновано провести характерну реакцію (C) на бромід-іон, а саме - з розчином хлораміну, у присутності кислоти хлористоводневої розведеної і хлорофрорму (хлороформний шар забарвлюється у жовто-бурий колір) [3]. Крім того, з огляду на сучасні методи стандартизації, зокрема ідентифрікації, запропоновано визначати відповідність ІЧ-спектра субстанції ІЧ-спектра фрармакопейного стандартного зразка (ФСЗ) та внести до МКЯ у розділ «Ідентифікація» наступне: інфррачервоний спектр поглинання субстанції, попередньо висушеної до постійної маси, в умовах, вказаних у розділі «Втрата в масі при висушуванні», одержаний у дисках з калію бромідом (1 мг субстанції в 200 мг калію броміду) в ділянці від 4000 до $400 \mathrm{~cm}^{-1}$ має відповідати спектру фрармакопейного стандартного зразка (ФСЗ), що додається [3]. Зразок спектра ФС3 броміду 1-( $\beta$-сренілетил)-4-аміно-1,2,4- триазолія (ДП «Завод хімічних реактивів» Науковотехнологічного комплексу «Інститут монокристалів» НАН України, Україна) наведено на рисунку 2.

Наступним завданням стала розробка методів кількісного визначення субстанції гіпертрилу. 3 огляду на вимоги діючої ДФУ, більшість субстанцій органічної природи, які мають лужні або кислотні властивості, кількісно визначають методом неводного титрування, що і було нами запропоновано [4, 3, 9]. По-перше, вивчено можливість титрування субстанції гіпертрилу 0,1 М розчином кислоти хлорної з використанням внутрішнього індикатора та визначенням точки еквівалентності потенціометрично. Як розчинник ми використовували оцтову кислоту безводну. В результаті дослідження було встановлено, що субстанція розчинна в оцтовій кислоті безводній тільки при тривалому нагріванні. Отримувані результати були задовільними і коливалися в межах від 98,5 до 101 \%. Але, спираючись на кількість часу, який потрібно на проведення одного аналізу, вважаємо, що ця методика $є$ недоцільною. Щоб зменшити тривалість часу аналізу субстанції гіпертрилу запропоновано попередньо розчиняти наважку в мурашиній кислоті безводній, а далі - додавати оцтову кислоту безводну. В ході аналізу субстанції гіпертрилу за цією методикою отримано нестабільні результати в

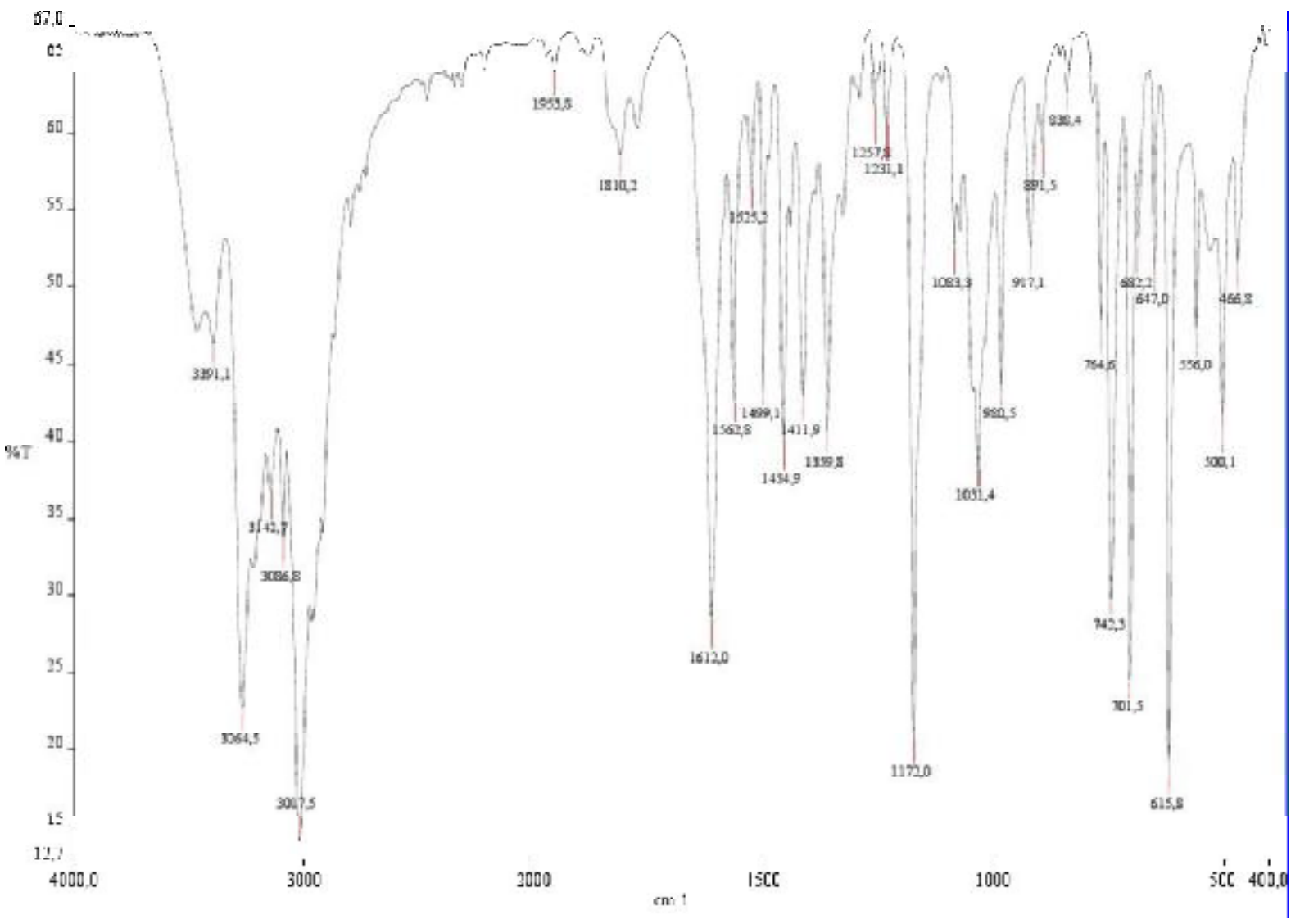

Рис. 2. Зразок спектра фрармакопейного стандартного зразка (ФСЗ) броміду 1-(ß-френілетил)-4-аміно-1,2,4триазолія.

ISSN 2312-0967. Pharmaceutical review. 2015. № 2 


\section{Analysis of drugs}

межах від 94 до 99,5 \%. В подальших дослідженнях ми як розчинник застосували суміш мурашиної кислоти безводної з оцтовим ангідридом. Як індикатор використовували кристалічний фріолетовий, а також випробовували можливість встановлення точки еквівалентності потенціометричним методом [4]. При використанні внутрішнього індикатора виникали труднощі, в зв'язку 3 тим, що перехід забарвлення був нечітким. Тому запропоновано встановлювати точку еквівалентності потенціометрично. В ході аналізу отримано стабільні результати, а час аналізу було скорочено майже втричі.

Методика кількісного визначення. Близько 0,2000 г субстанції (точна наважка), попередньо висушеної до постійної маси, розчиняють у 2 мл мурашиної кислоти безводної, додають 40 мл оцтового ангідриду і титрують 0,1 М розчином кислоти хлорної, кінець титрування визначають потенціометрично.

Паралельно проводять контрольний дослід.

1 мл 0,1 М розчину кислоти хлорної відповідає 26,92 мг $\mathrm{C}_{10} \mathrm{H}_{13} \mathrm{BrN}_{4}$.

Вміст гіпертрилу у відсотках розраховують за фрормулою:

$$
\mathrm{X} \%=\frac{\left(\mathrm{V}_{1}-V_{k}\right) \times T \times K_{n} \times 100 \%}{m},
$$

де $\mathrm{V}_{1}$ - об'єм титранта, витраченого на титрування наважки, мл;

$\mathrm{V}_{\mathrm{k}}$ - об'єм титранта, витраченого на контрольний дослід, мл;

Т - титр 0,1 М розчину кислоти хлорної по гіпертрилу;

$\mathrm{K}_{\mathrm{n}}$ - коефріцієнт поправки кислоти хлорної;

$\mathrm{m}$ - наважка гіпертрилу, г.

Результати аналізу шести серій субстанції гіпертрилу методом неводного титрування наведено в таблиці 1.

Згідно 3 результатами, наведеними в таблиці 1, можна зробити висновок, що розроблена нами методика визначення кількісного вмісту субстанції гіпертрилу методом неводного титрування є зручною та простою у виконанні, точною, відтворюваною та відповідає всім вимогам Державної фрармакопеї та міжнародним стандартам.

Таблиця 1. Результати кількісного визначення субстанції гіпертрилу методом неводного титрування

\begin{tabular}{|c|c|c|c|c|c|c|c|}
\hline Сполука & Серія & Наважка, г & V, мл & $\mathrm{V}_{\mathrm{k}}, \mathrm{M} \pi$ & $\mathrm{K}_{\mathrm{n}}$ & Вміст, \% & $\begin{array}{c}\text { Статистична } \\
\text { обробка }\end{array}$ \\
\hline Гіпертрил & 010213 & 0,1967 & 7,90 & 0,60 & 1,0000 & 99,90 & \multirow{6}{*}{$\begin{array}{c}\bar{X}=99,93333 \\
S^{2}=0,015667 \\
S=0,125167 \\
\Delta X=0,125193\end{array}$} \\
\hline Гіпертрил & 020213 & 0,2016 & 8,10 & 0,60 & 1,0000 & 100,15 & \\
\hline Гіпертрил & 010713 & 0,1995 & 8,00 & 0,60 & 1,0000 & 99,85 & \\
\hline Гіпертрил & 020713 & 0,1992 & 8,00 & 0,60 & 1,0000 & 100,00 & \\
\hline Гіпертрил & 030713 & 0,2048 & 8,20 & 0,60 & 1,0000 & 99,90 & \\
\hline Гіпертрил & $\begin{array}{l}\text { CZLGip- } \\
010614\end{array}$ & 0,1996 & 8,00 & 0,60 & 1,0000 & 99,80 & \\
\hline
\end{tabular}

Висновки. В ході проведених досліджень розроблено методики ідентифрікації та кількісного визначення вмісту субстанції гіпертрилу методом неводного титрування, які є чутливими, об'єктивними, надійними та відтворюваними.
У подальшому розроблені нами методики якісного та кількісного визначення субстанції гіпертрилу планується ввести в МКЯ на субстанцію гіпертрилу.

\section{Література}

1. Некоторые аспекты кардиопротекторного действия нового $\beta$-адреноблокатора с NO-миметическим эффектом «Гипертрил» на модели инфраркта миокарда / И. Ф. Беленичев, Л. И. Кучеренко, Ю. А. Волчик [та ін.] // Фармакологія та лікарська токсикологія. - 2014. № 4-5 (40) - С. 11-16.

2. Георгиевский Г. В. Разработка комплекса фризикохимических методик, обеспечивающих создание и контроль качества оригинальных отечественных препаратов, производных 1,2,4-триазола / Г. В. Георгиевский // Запорожский медицинский журнал. - 2011. - T. 13. - № 1. - С. 58-69.

3. Державна Фармакопея України / ДП «Науково- експертний фрармакопейний центр». - 1-е вид. - Х. , 2001. -672 c.

4. Розробка оптимальної методики визначення кількісного вмісту тіотриазоліну / Л. І. Кучеренко, Н. В. Парнюк, Л. І. Шаповалова [та ін.] // Актуальні питання фрармацевтичної і медичної науки та практики. - 2012. - № 2. - С. 48-50.

5. Взаимодействия анион‥т-система в кристалах бромида 4-амино-1-(ß-френилэтил)-1,2,4-триазолия / С. В. Шишкина, Р. И. Зубатюк, Л. И. Кучеренко [и др.] // Известия академии наук. Серия Химическая. - 2013. № 8. - С. 1900-1906.

6. Патент 2532394 Российская Федерация. МПК

ISSN 2312-0967. Фармацевтичний часопис. 2015. № 2 
A61K31/4196 (2006.01) A61P9/10 (2006.01) A61P43/00 (2006.01). Применение бромида 1-(бета-френилэтил)-4амино-1,2,4-триазолия (Гипертрил) как активной основы лекарственных средств для коррекции нарушений фрункционирования нитроксидергической системы органов-мишеней при гомоцистеинемии и острых нарушениях мозгового крообращения / И. А. Мазур, И. Ф. Беленичев, И. С. Чекман и др. ; заявитель и патентообладатель ООО НПО «Фарматрон». № 2013148306; заявл. 29.10.2013, опубл. 10.11.2014. 7. Патент 84351 Україна. МПКА61K 31/41 (2006.01), А61P 9/10 (2006.01). Застосування броміду 1-(ß-сренілетил)4-аміно-1,2,4-триазолію як активної основи лікарських засобів для корекції порушень фрункціонування нітроксидергічної системи при атеросклерозі і цукровому діабеті / Мазур І. А., Бєлєнічев І. Ф., Чекман І. С. та ін.; заявник і патентовласник ТОВ НВО «Фарматрон». № a201212500. Заяв. 02.11.2012, опубл. 25.10.2013.

8. Метаболитотропные препараты / [И. А. Мазур, И. С. Чекман, И. Ф. Беленичев и др.]. - Запорожье, 2007. - 304 c.

9. European Pharmacopoeia. - 6th-ed. Council of Europe. - Strasbourg, 2007. - 3857

10. White W. Blood pressure monitoring in cardiovascular medicine and therapeutics / W. White. - New Jersey: Humana Press, 2011.- 308 p.

11. Treatment of Hypertension in Patients 80 Years of Age or Older / N. S. Beckett, R. Peters, A. E. Fletchers [et al.] // N. Engl. J. Med. - 2011. - Vol. 358. - P. 1887-1888.

12. Coca A. Cerebral involvement in hypertensive cardiovascular disease / A. Coca // Eur. Heart J. - 2010. 5 (Suppl). - P. 19-25.

\title{
О СТАНДАРТИЗАЦИИ СУБСТАНЦИИ ГИПЕРТРИЛА
}

\section{Л. И. Кучеренко}

\section{Запорожский государственный медицинский университет НПО «Фарматрон»}

\begin{abstract}
Резюме: от наличия высокоэффективных конкурентоспособных лекарственных средств отечественного производства зависит эффрективность оказания медицинской помощи населению Украины. Особенно это касается лекарственных средств, применяемых для лечения заболеваний сердечно-сосудистой системы. Вышеупомянутое побудило к созданию принципиально нового антиангинального и антигипертензивного препарата оригинальной структуры - гипертрила. Поэтому целью нашей работы стала разработка методов стандартизации полученной субстанции. В настоящее время большое внимание уделяют новым, современным методам стандартизации субстанций. В ходе проведенных исследований нами разработаны методики стандартизации, а именно идентификации и количественного определения субстанции гипертрила, которые являются чувствительными, объективными, надежными и воспроизводимыми. В дальнейшем разработанные методики качественного и количественного определения планируется ввести в МКК на субстанцию гипертрила.
\end{abstract}

Ключевые слова: субстанция, гипертрил, стандартизация, идентификация, неводное титрование.

\section{ON THE STANDARDIZATION OF HYPERTRIL SUBSTANCE}

\section{I. Kucherenko}

\section{Zaporizhian State Medical University $S P C$ «Pharmatron»}

Summary: efficiency of health care service in Ukraine depends on the presence of highly effective competitive drugs of domestic production. Especially it concerns drugs used for treating of cardiovascular diseases. All about mentioned urge to develop perfectly new antianginal and antihypertensive remedy of original structure - Hypertril. Thus, the aim of this investigation is the development of standardization methods for received substance. At present time much attention is paid to new modern methods of standardization of substances. During performed investigation we worked out standardization methods namely identification and quantitative determination of Hypertril substance which are sensitive, objective, reliable and reproducible. Further worked out methods of qualitative and quantitative determination are planned to introduce into QCM for Hypertril substance

Key words: substance, Hypertril, standardization, identification, nonaqueous titration. 